University of Nebraska - Lincoln

DigitalCommons@University of Nebraska - Lincoln

Publications from USDA-ARS / UNL Faculty

U.S. Department of Agriculture: Agricultural

Research Service, Lincoln, Nebraska

2002

\title{
Incompatibility Systems in Switchgrass
}

J. M. Martinez-Reyna

University Autonoma Agraria Antonio Narro

Kenneth P. Vogel

University of Nebraska-Lincoln, kvogel1@unl.edu

Follow this and additional works at: https://digitalcommons.unl.edu/usdaarsfacpub

Martinez-Reyna, J. M. and Vogel, Kenneth P., "Incompatibility Systems in Switchgrass" (2002).

Publications from USDA-ARS / UNL Faculty. 1935.

https://digitalcommons.unl.edu/usdaarsfacpub/1935

This Article is brought to you for free and open access by the U.S. Department of Agriculture: Agricultural Research Service, Lincoln, Nebraska at DigitalCommons@University of Nebraska - Lincoln. It has been accepted for inclusion in Publications from USDA-ARS / UNL Faculty by an authorized administrator of DigitalCommons@University of Nebraska - Lincoln. 


\title{
CROP BREEDING, GENETICS \& CYTOLOGY
}

\author{
Incompatibility Systems in Switchgrass
}

\author{
J. M. Martínez-Reyna and K. P. Vogel*
}

\begin{abstract}
Switchgrass (Panicum virgatum L.), a cross-pollinated perennial, produces very little or no seed when self-pollinated, indicating the presence of self-incompatibility mechanisms. Knowledge of selfincompatibility mechanisms is required to use germplasm effectively in a breeding program. The objective of this study was to characterize features of the incompatibility systems in switchgrass. Seed set and seed characteristics of reciprocal matings of tetraploid, octaploid, and tetraploid $\times$ octaploid plants were used as measures of incompatibility. Both bagged mutual pollination and manual emasculation and pollination methods were used to make crosses. The percentages of selfcompatibility in the tetraploid and octaploid parent plants were 0.35 and $1.39 \%$, respectively. Prefertilization incompatibility in switchgrass is apparently under gametophytic control, since there were significant differences in percentage of compatible pollen as measured by percentage of total seed set between reciprocal matings within ploidy levels. Results indicated that the prefertilization incompatibility system in switchgrass is similar to the $S-Z$ incompatibility system found in other members of the Poaceae. A postfertilization incompatibility system also exists that inhibits intermatings among octaploid and tetraploid plants. In these interploidy crosses, two very distinctive types of abnormal seed were found. When the female parent was the tetraploid plant, the resulting seed was small and shriveled, while when the female parent was the octaploid, small seed with floury endosperm was obtained. These results are similar to those obtained for endosperm incompatibility due to the endosperm balance number system found in other species.
\end{abstract}

$\mathrm{P}$ LANTS OF SWITCHGRASS , a cross-pollinated perennial, produce very little or no seed when self-pollinated, indicating the presence of incompatibility mechanisms (Talbert et al., 1983; Taliaferro and Hopkins, 1996). Previous research reported the existence of self-incompatibility but did not identify or describe the self-incompatibility mechanisms of switchgrass. Knowledge of selfincompatibility mechanisms is required to utilize the available germplasm of a species effectively in a breeding program.

In a broad sense, incompatibility in plants can be defined as the inability of functional male and female gametes to produce normal seed following mating (Allard, 1964, p. 234-252). This includes not only the inability to produce embryos, but also the inability to

J.M. Martínez-Reyna, Univ. Autónoma Agraria Antonio Narro, Buenavista, Saltillo, Coahuila, México; K.P. Vogel, USDA-ARS, 344 Keim Hall, Univ. of Nebraska, P.O. Box 830937, Lincoln, NE 685830937. The research is from a dissertation submitted by the senior author in partial fulfillment of the requirements for a Ph.D. degree at University of Nebraska. The research was funded in part by the U.S. Dep. of Energy's Bioenergy Feedstock Development Program at Oak Ridge National Laboratory, USDA-ARS, CONACYT-México, and the University of Nebraska. Journal Series No. 13538 Nebraska Agric. Exp. Stn. Received November 26, 2001. *Corresponding author (kpv@unlserve.unl.edu).

Published in Crop Sci. 42:1800-1805 (2002). produce normal endosperm. Self-incompatibility can occur through a prefertilization mechanism that forces outcrossing by preventing self-fertilization. Self-incompatibility can be gametophytic or sporophytic. It is gametophytic if the incompatibility phenotype of pollen is determined by its own alleles, and sporophytic if the incompatibility phenotype of the pollen is determined by the genotype of the plant producing pollen (Brewbaker, 1957; Allard, 1964, p. 234-252; de Nettancourt, 1977).

Self-incompatibility has been reported in many members of the Poaceae. Lundqvist (1956) and Hayman (1956) established that self-incompatibility in some grasses is determined by the action of two independently segregating, polyallelic genes, $\mathrm{S}$ and $\mathrm{Z}$. The pollen grain is specified gametophytically by the complementary interaction of $\mathrm{S}$ and $\mathrm{Z}$ genes. A pollen grain will be incompatible with a style that has the same alleles. The S-Z self-incompatibility system is not broken down by polyploidy. In polyploid plants, not all alleles of the pollen need to be matched in the style to produce an incompatible reaction; any S-Z allelic combination present in the pollen grain, which is also present in the style, is sufficient to produce incompatibility (Lunqvist, 1957). The $\mathrm{S}-\mathrm{Z}$ incompatibility system is thought to be characteristic of the Poaceae as a whole but only a limited number of species have been studied thoroughly (Hayman, 1992; Heslop-Harrison 1982; de Nettancourt, 1977).

In the genetic analyses of the $\mathrm{S}-\mathrm{Z}$ incompatibility system, the percentage of seed produced or seed set can be used as an index of compatible pollination. Environmental conditions including effects of bagging under which the seed is obtained may reduce seed set. The two significant features of this system, which are the presence of both compatible and incompatible pollen in a cross (gametophytic control) and the differences in compatibility between reciprocal crosses (involvement of more than one locus), can be demonstrated by diallel analysis (Hayman, 1992) or alternative methods by structured matings (Weimarck, 1968).

In addition to prefertilization incompatibility, in some species a postfertilization incompatibility also occurs. Norrmann et al. (1994) studied the cross-compatibility between diploid and tetraploid plants of five species of Paspalum and found that three out of five of the species formed intraspecific hybrids at a very low frequency (less than $0.05 \%$ ). From the analysis of the crossed spikelets, they found that most of the seed was shriveled with a liquid endosperm and lacked starch or had sparse starch formation. Norrmann et al. (1994) concluded that the low diploid-tetraploid crossability was due to the existence of a postzygotic incompatibility system and not caused by prefertilization barriers. 
Similar results were obtained by Griffiths et al. (1971) in perennial ryegrass (Lolium perenne L.) when they tried to cross diploid and tetraploid plants. The frequency of triploid seedlings was very low, thereby suggesting incompatibility between the $n$ and $2 n$ gametes for the production of viable zygotes. Boyes and Thompson (1937) studied seed development in interspecific-interploidy crosses in Triticum. They found that when the parent with the larger chromosome number was the female parent, endosperm developed and although the seed was reduced in size, they were able to germinate. When the parent with the larger chromosome number was the male parent, the endosperm cell formation and differentiation was abnormal resulting in shriveled seed that failed to germinate. They attributed these reciprocal differences in seed development to the chromosome unbalance in the endosperm.

Brink and Cooper (1947) developed the concept that endosperm breakdown was the main reason for the failure in intra- and interspecific crosses in plants. The concept of Endosperm Balance Number (EBN) was proposed by Johnston et al. (1980) to explain endosperm development in both interploidy, intraspecific, and interspecific crosses. As proposed by Johnston et al. (1980), successful endosperm development requires that the EBN factors rather than the entire genomes must be in a 2:1 maternal:paternal ratio, i.e., each species has an effective EBN in the endosperm and it is the effective EBN, rather than the numerical (actual) ploidy levels that must be in a 2:1 maternal to paternal ratio for normal endosperm development. Ehlenfeldt and Hanneman (1988) observed that in Solanum species an extra EBN maternal dosage produced viable seed of reduced size, whereas any extra paternal dose resulted in seed abortion. Thus, although female and male EBN factors seem to be identical, their behavior is different and the specific balance of 2:1 is required for normal seed production. Ortiz and Ehlenfeldt (1992) indicated that EBN could be used to explain the results of interspecific-interploidy crosses of Datura stramonium L., $\mathrm{Cu}$ cumis spp., Dactylis spp., Glycine spp., Impatiens spp., Lotus spp., Lycopersicon spp., Medicago spp., Oryza spp., Phaseolus spp., Trifolium spp., Triticum spp., and Vaccinium spp.

Switchgrass has several ploidy levels. Nielsen (1944) reported chromosome numbers ranging from diploid $(2 n=2 x=18)$ to duodecaploid $(2 n=12 x=108)$. Recent studies indicate that switchgrass has primarily tetraploid and octaploid plants (Hopkins et al., 1996; Hultquist et al., 1997; Lu et al., 1998). Taliaferro and Hopkins (1996) obtained a crossability [(seed set/florets crossed)100] of $0.06 \%$ for the cross octaploid (female) by tetraploid (male) and no seed from the reciprocal cross. Tetra- and octaploid plants are often found in the same native prairies but hexaploids are rare (Brunken and Estes, 1975; Hultquist et al.,1997). These results indicate the existence of a strong genetic barrier that prevents seed flow between ploidy types of switchgrass. This study was conducted to determine the features of the incompatibility systems present in switchgrass.

\section{MATERIALS AND METHODS}

Three cultivars, Kanlow (K), Summer (S), and Pathfinder (P) (Alderson and Sharp, 1994) and three accessions collected from native prairies located in Illinois (IL62), South Dakota (SD4), and Iowa (IA25) were used in this research. Ploidy level and ecotypes of the plants used in this study were Kanlow (lowland tetraploid), Summer (upland tetraploid), Pathfinder (upland octaploid), IL62 (upland octaploid), SD4 (upland octaploid), and IA25 (upland octaploid). Each plant of a cultivar or accession is a heterozygous individual. Plants were grown in pots in a greenhouse with an 18-h photoperiod and a mean temperature of $28^{\circ} \mathrm{C}$. Greenhouse cultural practices including fertilization for optimal plant growth and development were followed during the duration of the study.

Plants of the two tetraploids cultivars were mated by means of the mutual pollination method. Panicles of paired plants were enclosed together in pollination bags $(120$ by $410 \mathrm{~mm})$ before anthesis, with bamboo stakes to support the bags. To ensure pollination only preanthesis panicles in which anthers were beginning to emerge were bagged. Bags were shaken daily about $1200 \mathrm{~h}$ to facilitate pollen dispersion. This method made it possible to obtain reciprocal crosses simultaneously. To estimate seed set from self-pollination, panicles of individual plants also were bagged. The same procedures were used to intermate octaploid plants.

Florets of ripe panicles were dissected to observe and measure the caryopsis to obtain the percentage of incompatibility. To distinguish unfertilized ovaries from small shriveled seeds, unfertilized ovaries were dissected and measured from selfpollinated panicles harvested at the same time as panicles with ripe seed. On the basis of these measurements, any ovary less than $0.6 \mathrm{~mm}$ in length was classified as an unfertilized ovary. The number of florets with unfertilized ovaries divided by the total number of dissected florets multiplied by 100 produced an estimate of incompatible pollen. This estimate was used instead of normal seed set, which is commonly used as an index of compatible pollination in the genetic analyses of selfincompatibility system, because dissection results demonstrated that two seed unit classes in addition to normal seed were produced when switchgrass plants were intermated. In all subsequent descriptions of hybridizations, female plants are listed first, followed by the male parent. Chi square was used to test the hypothesis that the proportion of compatible pollen between reciprocal crosses was the same using the 2 by 2 contingency table procedure (Snedecor and Cochran, 1989, p. 125-128).

Controlled interploidy crosses using the emasculation and hybridization technique described by Martínez-Reyna and Vogel (1998) were conducted in the greenhouse with tetraploid plants of Summer and Kanlow and octaploid plants of SD4 and IA25. Florets from each representative interploidy cross; K-15 $\times$ SD4-5 (tetraploid by octaploid) and SD4-5 $\times$ K-15 (octaploid by tetraploid) were systematically collected at 2, 6,10, and $15 \mathrm{~d}$ after pollination to observe seed development. The number following the hyphen after a cultivar or accession abbreviation refers to a single individual heterozygous plant. The octaploid cross SD4-5 × IA25-9 that was used as a control for normal development of the seed also was sampled on the same days. After the Day 15, florets of the crosses were sampled at intermittent intervals until the seed were mature. The florets were dissected and the caryopses were measured and photographed under a stereoscopic microscope to document their characteristics and developmental stage.

\section{RESULTS AND DISCUSSION}

The percentages of self-compatibility in the tetraploid and octaploid parent plants were 0.35 and $1.39 \%$, re- 


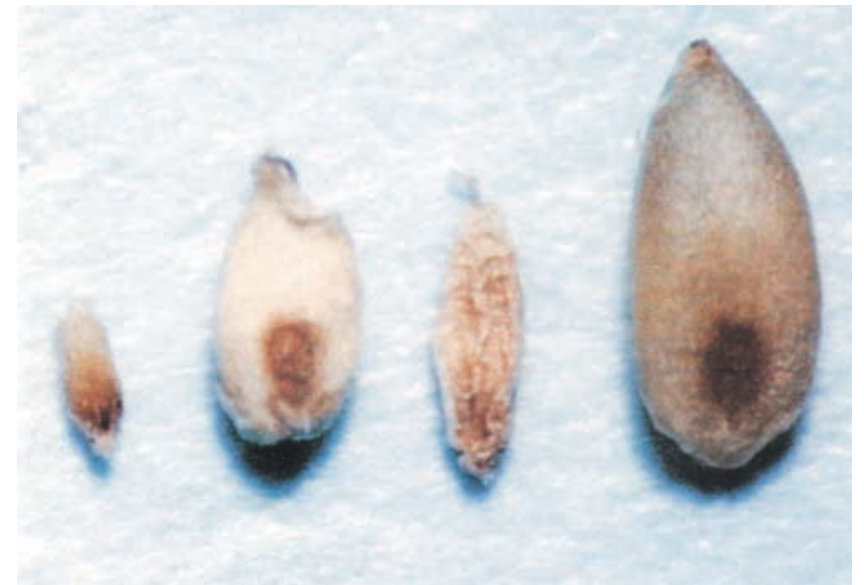

Fig. 1. Classes of switchgrass caryopsis development from a tetraploid by tetraploid cross. From left to right: unfertilized ovary; small caryopsis with limited endosperm development, i.e., endosperm is small and has a floury appearance; small caryopsis generally brownish in color with shriveled endosperm; and normal caryopsis. Magnification $\times 26$.

spectively. These percentages are very similar to those reported by Talbert et al. (1983) and Taliaferro and Hopkins (1996) and together they demonstrate that switchgrass is a highly self-incompatible species.

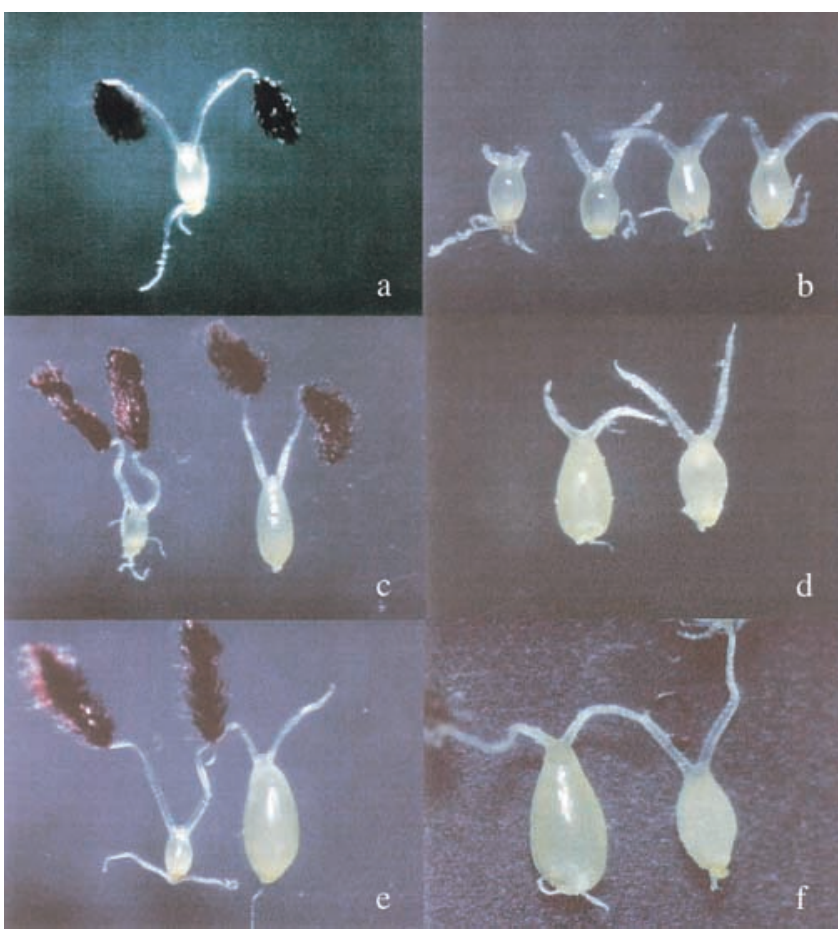

Fig. 2. (a). Caryopsis development of tetraploid by octaploid switchgrass cross $2 \mathrm{~d}$ after pollination. (b). Caryopsis development $2 \mathrm{~d}$ after pollination. From left to right; non-pollinated ovary, selfed octaploid, octaploid by tetraploid cross, and octaploid by octaploid cross (control). (c). Unfertilized ovary from tetraploid parent (left); caryopsis development of tetraploid by octaploid cross $6 \mathrm{~d}$ after pollination (right). (d). Caryopsis development of octaploid by octaploid cross (left) and octaploid by tetraploid cross (right) 6 d after pollination. (e). Unfertilized ovary from tetraploid parent (left); seed development of tetraploid by octaploid cross $10 \mathrm{~d}$ after pollination (right). (f). Caryopsis development of octaploid by octaploid cross (left) and octaploid by tetraploid cross (right) $10 \mathrm{~d}$ after pollination. Magnification is $26 \times$.
Dissection of the switchgrass florets demonstrated that three classes of seed development were produced by the matings, in addition to unfertilized ovaries. These classes were as follows: (i) small seed with limited endosperm development, (endosperm was small and had a floury appearance); (ii) small seed, generally brownish in color with shriveled endosperm, and (iii) normal seed (Fig. 1). The detection of two abnormal seed classes indicated that a postfertilization incompatibility system exists in switchgrass that is independent of the prefertilization barriers imposed in matings. We recognize that environmental factors in addition to genetic factors can affect fertilization and seed development. Since all plants were grown in the same greenhouse section during the same period of time and received the same cultural treatments, we assumed that environmental conditions affected all genotypes in a similar manner. We also assumed that the bags in which the panicles were enclosed did not differentially affect pollination and seed development of paired mated plants since conditions were the same for both parent plants.

Compatible and incompatible pollen were found in each cross (Table 1). If no embryo developed in a pollinated floret, we assumed the pollen was incompatible, while recognizing that failure of embryo development

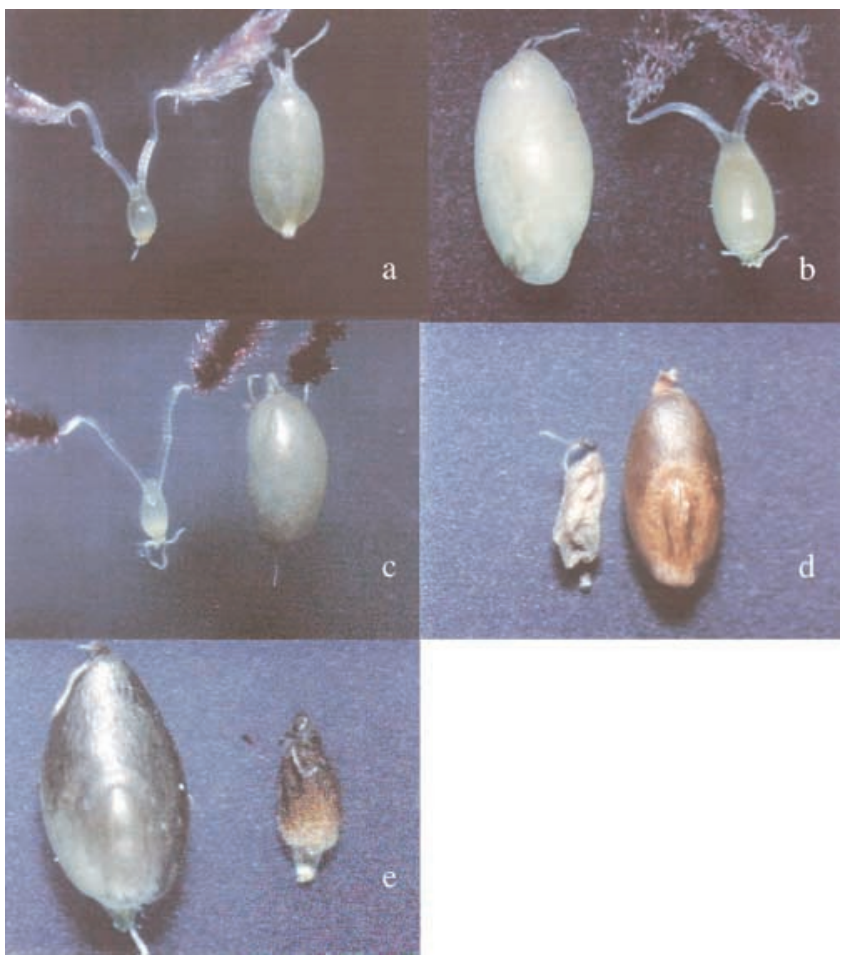

Fig. 3. (a). Unfertilized ovary from tetraploid switchgrass parent (left); caryopsis development of tetraploid by octaploid cross $15 \mathrm{~d}$ after pollination (right). (b). Caryopsis development of octaploid by octaploid cross (left) and octaploid by tetraploid cross (right) $15 \mathrm{~d}$ after pollination. (c). Unfertilized ovary from tetraploid parent (left). Seed development of tetraploid by octaploid cross $20 \mathrm{~d}$ after pollination (right). (d). Normal, mature seed from open pollinated, tetraploid parent (right); final stage of seed development of tetraploid by octaploid cross $36 \mathrm{~d}$ after pollination (left). (e). Normal, mature seed from octaploid by octaploid cross (left; final stage of seed development of octaploid by tetraploid cross $30 \mathrm{~d}$ after pollination (right). Magnification is $26 \times$. 
could reflect postzygotic environmental and genetic effects. If an embryo developed but without normal endosperm, it was assumed the pollen was compatible but there was postfertilization incompatibility. If normal seed was produced, pollen was compatible and no postfertilization incompatibility was present. As indicated previously, only unfertilized ovaries were used in the estimation of prefertilization incompatibility. This procedure classified all pollinations that produced any of the three seed classes as compatible even though normal seed may not have been produced. Therefore, the percentage of compatible pollen is the sum of abnormal seed and normal seeds divided by the total number of florets dissected per cross.

Certain crosses, i.e., K-1 by S-3 and its reciprocal, had the same normal seed set $(10 \%)$ (Table 1). By using normal seed set as an index of compatible pollination, it could be assumed that the incompatibility reaction involved in the reciprocal mating was the same. If the percentage of compatible pollen (percentage of abnormal and normal seed) is used as the estimate of the prefertilization incompatibility, there was a significant difference in pollen compatibility between parents for this and other reciprocal crosses (Table 1). Different percentages of compatible pollen were found within reciprocal crosses depending on which plant was the male or female parent for both tetraploids and octaploids (Table 1). These results indicate that prefertilization incompatibility in switchgrass is under gametophytic control and the involvement of more than one locus in determining incompatibility. These results indicated that the pre-fertilization incompatibility system in switchgrass is similar to the S-Z incompatibility system found in other members of the Poaceae. The number of alleles for each locus needs to be determined. This will require additional genetic studies using diallel mating and analysis. However, because of the high prefertilization incompatibility index found in most of the crosses, we believe that the number of alleles for the $S$ and $\mathrm{Z}$ loci might be relatively low in these switchgrass populations.

No normal seed were produced from 415 crossing attempts (16 crosses) between the reciprocal crosses of tetraploid by octaploid plants. Taliaferro and Hopkins (1996) reported similar results. They obtained only four seeds from 6242 crossing attempts in the same interploidy crosses. In this study floret dissection demonstrated that at $2 \mathrm{~d}$ after pollination, the development of

Table 1. Percentage of compatible and incompatible pollen in tetraploid (Kanlow and Summer) and octaploid (Pathfinder and IL62) crosses of switchgrass as determined by dissection of florets of ripened panicles. Crosses were produced via mutual pollination using pollination bags.

\begin{tabular}{|c|c|c|c|c|c|c|c|c|c|}
\hline Cross & $\begin{array}{l}\text { Female } \\
\text { parent } \dagger\end{array}$ & $\begin{array}{c}\text { Male } \\
\text { parent } \dagger\end{array}$ & $\begin{array}{c}\text { Florets } \\
\text { dissected }\end{array}$ & $\begin{array}{c}\text { Abnormal } \\
\text { seed } \%\end{array}$ & $\begin{array}{c}\text { Normal } \\
\text { seed set }\end{array}$ & $\begin{array}{c}\text { Compatible } \\
\text { pollenII }\end{array}$ & $\begin{array}{c}\text { Incompatible } \\
\text { pollen\# }\end{array}$ & $\chi^{2}$ & $P+\dagger$ \\
\hline & Tetraploids & & No. & 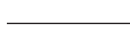 & 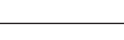 & $\%$ & & & \\
\hline \multirow[t]{2}{*}{1} & K-1 & S-3 & 90 & 63.4 & 10.0 & 73.4 & 26.6 & 50.01 & 0.00 \\
\hline & S-3 & K-1 & 120 & 13.4 & 10.0 & 23.4 & 76.6 & & \\
\hline \multirow[t]{2}{*}{2} & K-8 & S-9 & 82 & 8.5 & 0.0 & 8.5 & 91.5 & 28.48 & 0.00 \\
\hline & S-9 & K-8 & 83 & 19.5 & 27.7 & 47.2 & 53 & & \\
\hline \multirow[t]{2}{*}{3} & K-9 & S-22 & 100 & 41.0 & 7.0 & 48 & 52 & 32.07 & 0.00 \\
\hline & S-22 & K-9 & 102 & 4.9 & 5.9 & 10.8 & 89.2 & & \\
\hline \multirow[t]{2}{*}{4} & K-11 & S-12 & 95 & 4.2 & 4.2 & 8.4 & 91.6 & 3.72 & 0.05 \\
\hline & S-12 & K-11 & 94 & 6.4 & 12.8 & 19.2 & 80.8 & & \\
\hline \multirow[t]{2}{*}{5} & K-18 & S-42 & 78 & 3.8 & 2.6 & 6.4 & 93.6 & 18.91 & 0.00 \\
\hline & S-42 & K-18 & 87 & 8.0 & 27.6 & 35.6 & 63.2 & & \\
\hline \multirow[t]{2}{*}{6} & K-38 & S-37 & 96 & 0.0 & 2.1 & 2.1 & 97.9 & 137.52 & 0.00 \\
\hline & S-37 & K-38 & 89 & 71.9 & 16.8 & 88.8 & 11.2 & & \\
\hline \multirow[t]{2}{*}{7} & K-7 & K-6 & 65 & 18.4 & 9.2 & 27.6 & 72.4 & 6.02 & 0.01 \\
\hline & K-6 & K-7 & 97 & 10.3 & 1.0 & 11.3 & 88.7 & & \\
\hline \multirow[t]{2}{*}{8} & K-7 & K-8 & 92 & 5.4 & 0.0 & 5.4 & 94.6 & 3.38 & 0.06 \\
\hline & K-8 & K-7 & 94 & 0.0 & 0.0 & 0.0 & 100 & & \\
\hline \multirow[t]{3}{*}{9} & K-39 & K-38 & 100 & 3.0 & 9.0 & 12 & 88 & 12.39 & 0.00 \\
\hline & K-38 & K-39 & 90 & 15.7 & 18.8 & 34.5 & 65.5 & & \\
\hline & Octaploids & & & & & & & & \\
\hline \multirow[t]{2}{*}{10} & IL62-1 & P-1 & 86 & 6.9 & 65.1 & 72 & 28 & 50.29 & 0.00 \\
\hline & P-1 & IL62-1 & 174 & 0.0 & 25.3 & 25.3 & 74.7 & & \\
\hline \multirow[t]{2}{*}{11} & IL62-18 & P-22 & 106 & 4.6 & 27.4 & 32.0 & 68 & 24.48 & 0.00 \\
\hline & P-22 & IL62-18 & 88 & 55.7 & 15.9 & 71.6 & 28.4 & & \\
\hline \multirow[t]{2}{*}{12} & IL62-28 & P-10 & 103 & 27.1 & 2.9 & 30 & 70 & 39.34 & 0.00 \\
\hline & P-10 & IL62-28 & 92 & $\mathbf{7 6 . 0}$ & 0.0 & 76 & 24 & & \\
\hline \multirow[t]{2}{*}{13} & IL62-37 & P-13 & 96 & 10.4 & 10.4 & 20.8 & 79.2 & 10.58 & 0.00 \\
\hline & P-13 & IL62-37 & 101 & 39.6 & 4.0 & 43.6 & 56.4 & & \\
\hline \multirow[t]{2}{*}{14} & IL62-16 & IL62-28 & 96 & 12.5 & 11.5 & 24 & 76 & 0.01 & 0.92 \\
\hline & IL62-28 & IL62-16 & 122 & 4.1 & 21.3 & 25.4 & 74.6 & & \\
\hline \multirow[t]{2}{*}{14} & IL62-28 & IL62-18 & 102 & 12.8 & 12.7 & 25.5 & 74.5 & 0.35 & 0.55 \\
\hline & IL62-18 & IL62-28 & 100 & 16.0 & 5.0 & 21 & 79 & & \\
\hline \multirow[t]{2}{*}{16} & P-3 & P-2 & 97 & 14.5 & 15.5 & 30 & 70 & 25.31 & 0.00 \\
\hline & P-2 & P-3 & 66 & 14.9 & 56.1 & 71 & 29 & & \\
\hline \multirow[t]{2}{*}{17} & P-8 & P-6 & 136 & 27.2 & 30.8 & 58 & 42 & 2.99 & 0.08 \\
\hline & P-6 & P-8 & 85 & 50.6 & 20.0 & 70.6 & 29.4 & & \\
\hline
\end{tabular}

$\dagger \mathbf{K}=$ Kanlow, $\mathbf{S}=$ Summer, $\mathbf{P}=$ Pathfinder, IL = IL62, Plant ID number follows the hyphen.

+ Abnormal seed \% (Post-fertilization incompatibility index) $=[$ (abnormal seed/florets dissected)100].

$\S$ Seed set $\%$ (Crossability) $=$ [(normal seed set/florets dissected)100].

II Compatible pollen $\%=[($ abnormal seed + normal seed $) /$ florets dissected $) 100]$.

\# Incompatible pollen \% (Pre-fertilization incompatibility index) $=[($ unfertilized ovaries/florets dissected)100].

$t \dagger \chi^{2}$ tests that the proportion of compatible and incompatible pollen is the same for each separate direct and reciprocal cross. 
Table 2. Measurements of the seed development states of interploidy reciprocal crosses and intraploidy cross of switchgrass following fertilization.

\begin{tabular}{|c|c|c|c|c|c|c|c|c|c|c|c|c|}
\hline \multirow[b]{2}{*}{ Day } & \multicolumn{4}{|c|}{ K-15 $\times$ SD4-5† $+(4 x \times 8 x)$} & \multicolumn{4}{|c|}{ SD4-5 $\times$ K-15 $(8 x \times 4 x)$} & \multicolumn{4}{|c|}{ SD4-5 $\times$ IA25-9 $\div(8 x \times 8 x)$} \\
\hline & Length & SE & Width & SE & Length & SE & Width & SE & Length & SE & Width & SE \\
\hline & mm & & mm & & mm & & mm & & $\mathbf{m m}$ & & $\mathbf{m m}$ & \\
\hline 2 & 0.60 & 0.040 & 0.30 & 0.04 & 0.57 & 0.025 & 0.30 & 0.00 & 0.60 & 0.031 & 0.28 & 0.02 \\
\hline 6 & 0.77 & 0.047 & 0.32 & 0.05 & 0.90 & 0.047 & 0.47 & 0.02 & 1.14 & 0.050 & 0.60 & 0.03 \\
\hline 10 & 1.17 & 0.047 & 0.47 & 0.05 & 1.00 & 0.040 & 0.57 & 0.02 & 1.48 & $\mathbf{0 . 0 3 7}$ & 0.80 & 0.03 \\
\hline 15 & 1.50 & 0.040 & 0.57 & 0.05 & 1.22 & 0.047 & 0.72 & 0.05 & 2.44 & 0.050 & 1.22 & 0.02 \\
\hline 20 & 1.62 & 0.047 & 0.67 & 0.02 & $-\S$ & - & - & - & - & - & - & - \\
\hline 30 & - & - & - & - & 1.55 & 0.064 & 0.70 & 0.04 & 2.48 I & 0.020 & 1.48 I & 0.02 \\
\hline 36 & 1.37 & 0.020 & 0.47 & 0.02 & - & - & - & - & - & - & - & - \\
\hline
\end{tabular}

$\dagger$ Female parent listed first.

+ Control.

$\$$ Missing cells in this table denote data not enumerated.

II Normal seed size.

the caryopsis was similar for between and within ploidy level crosses (Fig. 2a and 2b). Six days after pollination some differences in caryopsis development were exhibited. Caryopses from the interploidy crosses grew slower than those from the control octaploid by octaploid cross seed (Fig. 2c and 2d). By Day 10, the differences in growth between octaploid $\times$ octaploid control cross and interploidy cross seed were more evident. At $10 \mathrm{~d}$ following pollination, the caryopsis in $4 x \times 8 x$ cross did not show signs of starch formation and the endosperm had a aqueous appearance (Fig. 2e and 2f). After 15 d, the caryopses from $8 x \times 4 x$ cross were only about one third of the size of the control caryopses, while caryopses from the $4 x \times 8 x$ cross were about half the size of the control (Table 2). The endosperm of the control and $8 x \times 4 x$ cross caryopses appeared solid while the endosperm of the $4 x \times 8 x$ cross caryopsis still had an aqueous appearance (Fig. 3a and 3b). As seed ripened, the endosperm of the seed from $4 x \times 8 x$ cross shriveled (Fig. $3 \mathrm{c})$ at about $20 \mathrm{~d}$ after pollination. The caryopsis of the $4 x \times 8 x$ seed appeared normal at this stage, although it was smaller than the caryopsis of the control seed (Table 2). Three days later ( $23 \mathrm{~d}$ after pollination) the shriveling process was more evident in $4 x \times 8 x$ cross and at the $36 \mathrm{~d}$ after pollination the caryopsis was completely shriveled (Fig. 3d). At 30 d, the caryopsis from $8 x \times$ $4 x$ cross differed in appearance from the seed of the reciprocal cross $(4 x \times 8 x)$. It did not undergo a shriveling process. However, the endosperm of the $8 x \times 4 \mathrm{x}$ cross was floury in appearance and the final size of the caryopsis is about one third the size of the control $8 x \times$ $8 x$ caryopsis (Table 2 ). The control caryopsis at this stage has a healthy vitreous appearance, typical of the normal switchgrass caryopsis (Fig. 3e).

Two distinctive types of seed were found in interploidy crosses. When the female parent was a tetraploid plant the resulting seed was a small and shriveled. When the female parent was an octaploid plant, small seed with floury endosperm were obtained. Similar results were obtained by Norrmann et al. (1994) and Boyes and Thompson (1937) from interploidy mating in Paspalum and Triticum species, respectively. The theory of EBN by Johnston et al. (1980) may explain the results from the ploidy level crosses in switchgrass. In a tetraploid by octaploid cross in switchgrass, the ratio would be 2:2 maternal/paternal EBN and would result in seed abortion since there is an extra paternal dose. Whereas in an octaploid by tetraploid cross the ratio would be 4:1 maternal/paternal EBN (i.e., an extra maternal EBN dose that produces two extra doses in the central cell) and would result in viable seed of reduced size. These results predicted by considering the EBN hypothesis are consistent with those obtained in this study.

\section{SUMMARY}

Self-pollination in switchgrass produced the maximum expression of prefertilization incompatibility (selfincompatibility) resulting in no expression of postfertilization incompatibility. Cross-pollination allows both prefertilization and postfertilization incompatibility to be expressed. The maximum expression of postfertilization incompatibility occurs in interploidy matings, but prefertilization incompatibility also can be present. Our results indicate that in switchgrass a prefertilization incompatibility system exists that resembles the S-Z system previously reported in the Poaceae (Lundqvist, 1956; Hayman, 1956). A postfertilization incompatibility system also exists that inhibits intermatings between plants with different ploidy levels (octaploids and tetraploids) that is similar to the endosperm balance number system found in other species including Dactylis. The postfertilization incompatibility system that exists between switchgrass plants with different ploidy levels explains the lack of hexaploid plants in native prairies that contain both octaploid and tetraploid plants.

Our results suggest that postfertilization processes exists in both tetraploid and octaploid switchgrass plants that affect normal seed development because two classes of abnormal seed were obtained from within ploidy level matings. Additional research is needed to fully resolve the pre- and postfertilization incompatibility systems and processes that exist in switchgrass. If the mechanisms of these systems are determined, it may be feasible to use them and, in particular, the prefertilization self-incompatibility system, to produce hybrid switchgrass cultivars using procedures described previously by Vogel (2000).

\section{REFERENCES}

Alderson, J., and W.C. Sharp. 1994. Grass varieties in the United States. Agricultural Handbook No. 170. Soil Conservation Service, U.S. Dep. of Agric., Washington, DC. 
Allard, R.W. 1964. Principles of plant breeding. John Wiley, New York.

Boyes, J.W., and W.P. Thompson. 1937. The development of the endosperm and embryo in reciprocal interspecific crosses in cereals. J. Genet. 24:14-227.

Brewbaker, J.L. 1957. Pollen cytology and self-incompatibility systems in plants. J. Hered. 48:271-277.

Brink, R.A., and D.C. Cooper. 1947. The endosperm in seed development. Bot. Rev. 13:423-541.

Brunken, J.N., and J.R. Estes. 1975. Cytological and morphological variation in Panicum virgatum L. Southwest. Nat. 19:379-385.

de Nettancourt, D. 1977. Incompatibility in angiosperms. Spring-Verlag, New York.

Ehlenfeldt, M.K., and R.E. Hanneman Jr. 1988. Genetic control of Endosperm Balance Number (EBN): Three additive loci in a threshold-like system. Theor Appl. Genet. 75:825-832.

Griffiths, D.J., R.A.D. Pegler, and T. Tonguthaisri. 1971. Cross compatibility between diploid and tetraploid perennial ryegrass $(\mathrm{Lol}$ ium perenne L.). Euphytica 20:102-112.

Hayman, D.L. 1956. The genetic control of incompatibility in Phalaris coerulescens. Aust. J. Biol. Sci. 9:321-331.

Hayman, D.L. 1992. The S-Z incompatibility system. p. 117-137. In G.P. Chapman (ed.) Grass evolution and domestication. Cambridge Univ. Press, Cambridge, England.

Heslop-Harrison, J. 1982. Pollen-stigma interaction and cross-incompatibility in the grasses. Science 210:1358-1364.

Hopkins, A.S., C.M. Taliaferro, C.D. Murphy, and C. D'Ann. 1996. Chromosome number and nuclear DNA content variation among switchgrass populations. Crop Sci. 36:1192-1195.

Hultquist, S.J., K.P. Vogel, D.J. Lee, K. Arumuganathan, and S. Kaeppler. 1997. DNA content and chloroplast DNA polymorphisms among switchgrasses from remnant Midwestern prairies. Crop Sci. 37:595-598.

Johnston, S.A., T.P.N. de Nijs, S.J. Peloquin, and R.E. Hanneman Jr.
1980. The significance of genic balance to endosperm development in interspecific crosses. Theor. Appl. Genet. 57:5-6.

Lu, K., S.M. Kaeppler, K.P. Vogel, K. Arumuganathan, and D.J. Lee. 1998. Nuclear DNA content and chromosome numbers in switchgrass. Great Plains Res. 8:269-280.

Lundqvist, A. 1956. Self-incompatibility in rye. I. Genetic control in the diploid. Hereditas 42: 293-348.

Lundqvist, A. 1957. Self-incompatibility in rye. II. Genetic control in the tetraploid. Hereditas 43: 467-511.

Martínez-Reyna, J.M., and K.P. Vogel. 1998. Controlled hybridization technique for switchgrass. Crop Sci. 38:876-878.

Nielsen, E.L. 1944. Analysis of variation in Panicum virgatum. J. Agric. Res. 69:327-353.

Norrmann, G.A., O.A. Bovo, and C.L. Quarn. 1994. Post-zygotic seed abortion in sexual diploid $\times$ apomictic tetraploid intraspecific Paspalum crosses. Aust. J. Bot. 42:449-456.

Ortiz, R., and M.K Ehlenfeldt. 1992. The importance of Endosperm Balance Number in potato breeding and the evolution of tuberbearing Solanum species. Euphytica 60:105-113.

Snedecor, G., and W.G. Cochran. 1989. Statistical methods. 8th ed. Iowa State Univ. Press. Ames, IA.

Talbert, L.E., D.H. Timothy, J.C. Burns, J.O. Rawlings, and R.H. Moll. 1983. Estimates of genetic parameters in Switchgrass. Crop Sci. 23:725-728.

Taliaferro, C.M., and A.A. Hopkins. 1996. Breeding characteristics and improvement potential of switchgrass.p. 2-9. In J.S. Cundiff et al. (ed.) Proceedings of the Third Liquid Fuel Conference, Nashville, TN. 15-17 Sept. 1996. ASAE, St. Joseph, MI.

Vogel, K.P. 2000. Improving warm-season grasses using selection, breeding, and biotechnology. p. 83-106. In K.J. Moore and B. Anderson (ed.) Native warm-season grasses: Research trends and issues. Crop Sci. Spec. Publ. 30. CSSA and ASA, Madison, WI.

Weimarck, A. 1968. Self-incompatibility in the Gramineae. Hereditas 60:157-166 